\title{
ANALISIS MANAJEMEN SUMBER DAYA INSANI PADA BANK PEMBIAYAAN RAKYAT SYARIAH
}

\author{
Linda Saria \\ Ridan Muhtadib \\ Mansurc \\ a,b,c Program Studi Ekonomi Syariah, STAI Miftahul Ulum, Pamekasan. \\ Email: lindalinda.sari.2607@gmail.com; ridanmuhtadi@gmail.com; elcmansur@gmail.com
}

\begin{abstract}
Introduction: This study will analyze the human resource management at PT. BPRS Sarana Prima Mandiri Pamekasan in terms of recruitment and selection, training and employee development as well as employee performance appraisals.

Methods: The research methodology used by researchers is descriptive qualitative which will explain the events and circumstances in detail and perfectly with data collection techniques using observation, interviews and documentation.

Results: This research is deemed necessary considering that the development of Islamic banking in Indonesia is relatively fast but is still not balanced with adequate human resources, both in quality and quantity. and one of the company's mission is supported by human resources.

Conclusion and suggestion: This study indicates that human resource management at PT. BPRS Sarana Prima Mandiri (SPM) Pamekasan in terms of recruitment and selection is in accordance with sharia theory. Likewise, the work appraisal process is in accordance with the Islamic concept. However, in the training and development process, according to researchers, there is still a lack of material balance, namely between the material of Tauhid (Akhlak), Shari'ah, and Muamalah which is conveyed to employees when the training is carried out.
\end{abstract}

Keywords: Islamic banking, recruitment and selection, training and development, employee performance appraisal.

\section{PENDAHULUAN}

Aktivitas usaha bisnis yang berlandaskan syariah di Indonesia selalu mengalami peningkatan mulai dari perbankan syariah, pegadaian syariah, asuransi syariah hingga koperasi yang berbasis syariah. Bank Umum Syariah per Juni 2018 secara kuantitas telah berjumlah 34 unit yang terdiri dari Bank Umum Syariah (BUS) sebanyak 13 unit dan 21 Unit Usaha Syariah, di tahun yang sama Bank Pembiayaan Rakyat Syariah (BPRS) juga telah mencapai jumlah 168 unit. ${ }^{1}$ Pertumbuhan yang sangat pesat terjadi pada perbankan

\footnotetext{
${ }^{1}$ Ervicaninda Herry dkk., "Total Quality Management Development and Sharia Governance Efforts in Sharia Micro Financial Institutions to Improve Market Share," IJIEEB: International Journal of Integrated Education, Engineering and Business 2, no. 1 (2019): 27-35, https://doi.org/10.29138/ijieeb.v2i1.809.
} 
syariah, hal ini sesuai dengan market share syariah yang tekah mencapai 5\%. Otoritas Jasa Keuangan atau biasa disingkat dengan "OJK" telah mencatat pangsa pasar perbankan syariah terus meningkat. Terhitung sejak tahun 2017 pangsa pasar perbankan syariah sudah mencapai 5,44\% dan ditahun 2018 mengalami peningkatan sebesar sebesar 0,26\% dengan jumlah persentase pangsa pasar perbankan syariah yang mencapai $5.7 \%$ dan pangsa pasar perbankan syariah pada tahun 2019 berjumlah 5,99\% yang mengalami kenaikan sebesar 0,29\% dari pencapaian yang terjadi pada tahun 2020.2 Perkembangan perbankan syariah juga diketahui dari semakin banyaknya jumlah bank syariah yang terhitung sejak tahun 2009 berjumlah 1.223 sampai pada tahun 2014 mengalami peningkatan yang berjumlah sekitar 2.910 kantor. $^{3}$

Pertumbuhan lembaga keungan syariah khususnya perbankan syariah di Indonesia yang terbilang cepat, seharusnya diseimbangi diseimbangi dengan sumber daya insani (SDI) yang professional dalam bidangnya baik dari aspek kualitas dan kauntitasnya. Sebab, sumber daya insani (SDI) yang professional dalam bidangnya akan berpengaruh terhadap transaksi dan praktik dilapangan yang sering kali defleksi. Beberapa praktik nantinya akan menyimpang dan tidak sesuai syariah akibat ketidak tahuan sumber daya insani (SDI) akan dasar ekonomi syariah. ${ }^{4}$

Berdasarkan data Bank Indonesia mengungkapkan masalah sumber daya insani (SDI) yang sekitar sembilan puluh persen tenaga kerja di perbankan syariah tidak mempunyai background pendidikan ekonomi syariah atau perbankan syariah. Jumlah SDI yang ada di perbankan syariah didominasi oleh tenaga kerja pendidikan umum. Hal ini diungkapkan pada tayangan Economic Challenges pada 7 juni 2016 di metro TV yang datanya diperoleh dari Bank Indonesia. ${ }^{5}$

Kehilangan SDI yang professional menandakan suatu kerugian bagi perusahaan itu sendiri termasuk perbankan syariah karena SDI merupakan salah satu sumber daya yang akan menggerakkan aktivitas yang ada didalam perusahaan tersebut. SDI menjadi salah satu faktor penting disetiap proses pencapaian serta berbagai macam visi dan misi dari setiap perusahaan karena SDI dari sumber daya lainnya yaitu memiliki akal perasaan, keinginan, keterampilan, pengetahuan, dorongan, daya dan karya. Semua potensi SDI tersebut berpengaruh terhadap upaya perusahaan dalam mencapai tujuan. ${ }^{6}$ Maka,

\footnotetext{
${ }^{2}$ Muslikhin, M., Kinanti, R. A., Muhtadi, R., \& Fudholi, M. PEMERIKSAAN EMPIRIS PADA PENGARUH KINERJA SOSIAL TERHADAP PROFITABILITAS DI BANK SYARIAH. Ulumuna: Jurnal Studi Keislaman, 6(1), 2020. 72 84. Lihat juga, Rosyadah, P. C., Arifin, N. R., Muhtadi, R., \& Safik, M. (2020). Factors That Affect Savings In Islamic Banking. AL-ARBAH: Journal of Islamic Finance and Banking, 2(1), 33-46.

${ }^{3}$ Ridan Muhtadi, “SINERGISME BAITUL MAAL WA TAMWIL ( BMT ) DENGAN BADAN," 2015, 143-52.

4 Sari Rezeki Harahap, "PENGARUH STRATEGI PENGEMBANGAN SUMBER DAYA INSANI TERHADAP PENINGKATAN KINERJA DAN MUTU PELAYANAN PADA PT. BANK MUAMALAT INDONESIA, Tbk CABANG MEDAN," Journal Analytica Islamica 5, no. 1 (8 Mei 2016): 149-68.

5 90\% Pegawai Perbankan Syariah Tidak Berlatar Pendidikan Ekonomi Syariah, diakses 26 Januari 2021, https://https://www.metrotvnews.com/play/bD7UA1PE-90-pegawai-perbankan-syariah-tidak-berlatarpendidikan-ekonomi-syariah.

${ }^{6}$ Edy Sutrisno, Manajemen Sumber Daya Manusia (Jakarta: Kencana prenada media group, 2011).
} 
kehilangan SDI yang professional menandakan suatu kerugian bagi perusahaan itu sendiri. Hal ini mengharuskan SDI yang da didalam perusahaan harus terkelola dengan baik. Selain itu juga memerlukan manajemen yang tepat untuk mengatur dan memanfaatkan SDI dengan efektif, produktif serta efisien. Menurut Abdul Aziz yang mengutip dari James A.F Stoner menyatakan: maka dari itu SDI harus memiliki empat fungsi dasar yang juga merupakan prinsip manajemen yaitu; perencanaan, pengorganisasian, perngarahan dan pengontrolan. ${ }^{7}$

SDI dalam bidang manajemen utamanya dalam perusahaan memiliki cakupan ruang lingkup yang cukup luas salah satunya yaitu untul mengatur mengenai perencanaan SDI yang terdiri dari tahap pencarian SDI melalui proses rekrutmen dan seleksi calon karyawan, pelatihan dan pengembangan karyawan, penilaian kinerja karyawan, kepemimpinan sampai pada tahap pemutusan kerja ${ }^{8}$. Memperhatikan luasnya ruang lingkup serta pembahasan tentang manajemen SDI, maka penelitian kali ini akan lebih memfokuskan terhadap pengimplementasian manajemen SDI dari proses rekrutmen dan seleksi calon karyawan, pelatihan da pengembangan karyawan serta penilaian kinerja karyawan yang telah diterapkan di PT. BPRS Sarana Prima Mandiri (SPM) Pamekasan.

Berbeda dengan penelitian yang sebelumnya telah dilakukan oleh Anisatul Maghfiroh yang menegaskan bahwa kualitas dari sumber daya manusia yang ada dalam suatu lembaga keuangan syariah akan membantu lembaga keungan syariah tersebut untuk lebih berkembang dan mencapai tujuan yang telah direnanakan. Namun tidak cukup dari indokator sumber daya manusia secara kualitasnya saja, tapi harus paham tentang Islam juga. Oleh karena itu nilai-nilai Islam menjadi sangat penting untuk dimiliki oleh sumber daya manusia yang berkualitas dalam memajukan perbankan syariah. Judul penelitian terdahulu yaitu "Analisis Manajemen Sumber Daya Manusia dalam Perspektif Syariah di BPRS Sarana Prima Mandiri Bangkalan” yang menyebutkan bahwa sekitar 44\% sumber daya manusia yang tergabung didalamnya dari tingkat pendidikan sudah sesuai dengan bidangnya. Namun tidak ada yang berlatar belakang pendidikan Islam, hal ini menunjukkan bahawa BPRS Sarana Prima Mandiri masih kekurangan sumber daya manusia yang cakap dibidang ekonomi syariah. Peneliti terdahulu memfokuskan untuk melakukan penelitian mengenai pengembangan sumber daya manusia di BPRS Sarana Prima Mandiri cabang Bangkalan dengan menyimpulkan bahwa pengembangan sumber daya manusia dilakukan dengan teknik pemberian pelatihan dan pendidikan menegenai keterampilan dan kemampuan serta tingkah laku yang sesuai dengan spesifikasi pekerjaan masing-masing. Pelatihan dan pendidikan dalam tahapan pengembangan karywan diberikan kepada semua karyawan yang ada dalam perusahaan tersebut. Menurut peneliti terdahulu dalam proses pengembangan sumber daya manusia yang

\footnotetext{
${ }^{7}$ Abdul Aziz, Manajemen Investasi Syariah (Bandung: alfabeta, 2010).

${ }^{8}$ Yani Suryani dan Cecep Darmawan, Kiat Sukses Manajemen Rasulullah :Manajemen Sumber daya Insani Berbasis Nilai-nilai Ilahiyah (Bandung: Khazanah Intelektual, 2006).
} 
diterapkan di PT. BPRS Sarana Prima Mandiri (SPM) cabang Bangkalan masih tidak mempraktikan atau mengamalkan mengenai konsep syariah competence.

PT. BPRS Sarana Prima Mandiri (SPM) Pamekasan adalah salah satu lembaga keuangan syariah yang sama seperti halnya lembaga-lembaga keungan syariah pada umumnya yang juga melakukan perekrutan SDI untuk tergabung didalamnya. Berdasarkan data karyawan yang dimiliki oleh PT. BPRS SPM Pamekasan menunjukkan tenaga kerja yang tergabung didalamnya berjumlah 53 karyawan yang terbagi sebagai berikut; kantor pusat terdiri 30 karyawan, kantor kas Larangan terdiri dari 5 karyawan, kantor kas Bandaran terdiri dari 4 orang, kantor payment Ummul Qura terdiri dari 2 karyawan dan 13 karyawan berada di kantor cabang Bangkalan. SDI PT. BPRS SPM Pamekasan mengalami hal yang sama yaitu adanya karyawan PT. BPRS SPM Pamekasan yang bukan dari lulusan ekonomi syariah atau perbankan syariah, bahkan ada juga pendidikan terakhir yang ditempuh cukup Sekolah Menengah Atas (SMA), ada juga karyawan yang mengalami transisi yang awalnya bekerja di bank yang berstatus konvensional lalu beralih ke bank SPM syariah pamekasan.

Penelitian ini dianggap perlu untuk mengetahui bagaimana upaya PT. BPRS Sarana Prima Mandiri (SPM) Pamekasan terhadap penerapan manajemen sumber daya insani mulai dari aspek rekrutmen dan seleksi calon karyawan, pelatihan dan pengembangan karyawan sampai pada penilaian kinerja karyawan.

\section{LITERATURE REVIEW}

\section{Pengertian Sumber Daya Insani}

Sumber daya insani adalah sebutan lain dari sumber daya manusia, kata insani berarti bersifat atau menyangkut manusia, kemanusiaan atau manusiawi. ${ }^{9}$ Konsep dari "Insani" memiliki makna makhluk basyariyyah yang menunjukan pada aktivitas biologis, fisiologis atau material dan juga aktivitas insani berkaitan dengan aktivitas intelektual dan ruhaniyah. ${ }^{10}$ Dalam konteks ilmu manajemen syariah, sumber daya insani harus memiliki karakteristik atau sifat-sifat yang megarah pada sifat-sifat para Nabi. Sifat-sifat tersebut yaitu; shiddiq (benar), itqan (professional), fathanah (cerdas), amanah (jujur/terpercaya) dan tabligh (transparan) sebagai dasar serta kebenaran dalam menjalani kehidupan di muka bumi ini. ${ }^{11}$

Sumber daya insani atau biasa disebut dengan SDI adalah sumber daya yang sangat penting yang ada didalam suatu perusahaan karena sumber daya insani inilah yang nanti akan menjalankan setiap rangkaian aktivitas bahkan sampai pada tahapan pencapaian setiap tujuan dari suatu perusahaan oleh karena itu SDI menjadi sumber daya yang paling utrama yang ada didalam suatu perusahaan (Meldona, 2009:15). Sumber

\footnotetext{
${ }^{9}$ Muhammad Ali, Kamus Lengkap Bahasa Indonesia Modern (Jakarta: Pustaka Amani, 2006).

${ }^{10}$ Suryani dan Darmawan, Kiat Sukses Manajemen Rasulullah :Manajemen Sumber daya Insani Berbasis Nilainilai Ilahiyah.

${ }^{11}$ Lubis, M. Z. M. POLA REKRUTMEN DAN SELEKSI KARYAWAN PADA BMT. FreakonomicS: Journal of Islamic Economics and Finance, 1(1), 2020. 23-33.
} 
daya insani dalam menajalani kegiatan serta setiap aktivitasnya dalam Islam dianjurkan untuk melakukan hal-hal yang ma'ruf juga menjauhi setiap perkara yang mungkar serta harus senatiasa untuk selalu beriman kepada Allah SWT. Sebagaimana yang telah tercantum dalam Q.S Ali-Imran: 3:110.

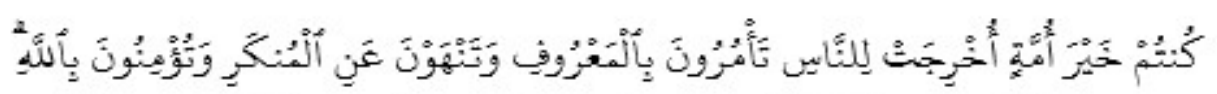

Artinya: "Kamu adalah umat yang terbaik yang dilahirkan untuk manusia, menyuruh kepada yang ma'ruf, dan mencegah dari yang munkar, dan beriman kepada Allah."

\section{Manajemen Sumber Daya Insani}

Manajemen sumber daya insani merupakan suatu pengelolaan, pemanfaatan serta pendayagunaan yang khusus untuk mengatur sumber daya insani yang ada didalam suatu perusahaan untuk mencapai tujuan-tujuan yang berhubungan dengan perusahaan. ${ }^{12}$ Manajemen sumber daya insani adalah suatu bidang manajemen yang khusus mempelajari hubungan dan peranan manusia atau insani dalam perusaahaan, yaitu mengenai pengaturan peranan manusia atau insan dalam mewujudkan tujuan perusahaan, kepuasan karywan dan masyarakat secara optimal. ${ }^{13}$

Sumber daya insani merupakan bagian khusus dari manajemen yang pembahasannya lebih spesifik terhadap peranan manusia atau insani itu sendiri untuk mencapai tujuan dari perusahaan secara efektif dan efisien serta pengoptimalan kenyaman serta keamanan karyawan juga masyarakat. ${ }^{14}$ Salah satu fungsi dari penerapan manajemen sumber daya insani dalam suatu perusahaan atau organisasi yaitu untuk mengelola dan mengatur setiap aktivitas untuk memudahkan pencapaian dari tujuan perusahaan. ${ }^{15}$

Menurut Edwin B. Flippo yang dikutip oleh Burhanuddin Yusuf menyebutkan bahwa manajemen sumber daya manusia merupakan suatu perencanaan, pengorganisasian, pengarahan dan pengawasan serangkai aktivitas yang meliputi pengadaan, pemberian kompensasi, pengembangan, pemeliharaan, pengintegrasian dan pelepasan sumber daya manusia untuk tercapainya tujuaan-tujuan baik seacara individu,

\footnotetext{
12 Eka Sri Wahyuni, "TELAAH KRITIS PENERAPAN MANAJEMEN SUMBER DAYA INSANI PADA PERUSAHAAN (Studi Empiris Pada PT. Bank Muamalat Indonesia, Tbk. Cabang Bengkulu," Jurnal BAABU AL-ILMI: Ekonomi dan Perbankan Syariah 2, no. 1 (25 April 2017), https://doi.org/10.29300/ba.v2i1.1051. 13 Azizah Nur Alfi, "Pangsa Pasar Bank Syariah Belum Naik Signifikan, Ini Tantangannya | Finansial," Bisnis.Com, 3 September 2020, bag. FINANSIAL, https://finansial.bisnis.com/read/20200903/90/1286919/pangsa-pasar-bank-syariah-belum-naiksignifikan-ini-tantangannya.

14 Marihot Tua Efendi Hariandja, Manajemen Sumber Daya Manusia, (Jakarta: PT Gramedia Widiasarana Indonesia, 2002), hal.3.

${ }^{15}$ Lubis, M. Z. M. POLA REKRUTMEN DAN SELEKSI KARYAWAN PADA BMT. FreakonomicS: Journal of Islamic Economics and Finance, 1(1), 2020. 23-33.
} 
organisasi bahkan masyarakat. ${ }^{16}$ Dessler menyatakan manajemen Sumber daya manusia merupakan serangkaian proses dalam memperoleh pegawai, melatih pegawai, menilai dan memberikan kompensasi kepada pegawai, memperhatikan hubungan kerja mereka, masalah keadilan, kesehatan dan keamanan pegawai yang ada di perusahaan tersebut. ${ }^{17}$ Manajemen sumber daya manusia adalah suatu peraturan dalam pelaksanaan aktivitas sumber daya manusia dari berbagai aspek manajemen yang didalamnya meliputi perekrutan, memilih, melatih, memberikan penghargaan, menilai bahkan sampai pemberhentian. ${ }^{18}$

\section{Rekrutmen dan Seleksi}

Rekrutmen merupakan tahapan awal dari proses perencanaan sumber daya insani. ${ }^{19}$ Rekrutmen adalah upaya untuk mendapatkan dan memilih caloin karyawan atau tenaga kerja yang sesuai dengan keahlian serta potensi baik itu secara kualitas maupun kuantitas sesuai dengan profesi yang dibutuhkan dan diperlukan oleh perusahaan. Tenaga kerja atau karyawan yang dipilih atau diterima oleh pihak perusahaan mempertimbangkan kemampuannya untuk menjalankan serta mencapai setiap visi dan misi perusahaan. ${ }^{20}$

Islam menganjurkan dalam pemilihan pegawai harus berdasarkan pengetahuan, kemapuan teknis dan pengalaman yang dimilikinya. Hal tersebut sesuai dengan firman Allah SWT., dalam QS. Al-Qashas ayat 26..21

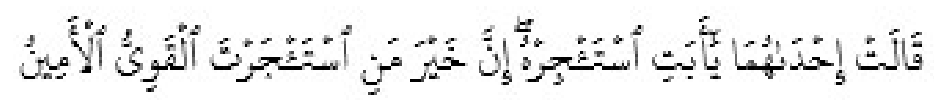

Artinya: Salah seorang dari kedua wanita itu berkata: "Ya bapakku ambillah ia sebagai orang yang bekerja (pada kita), karena sesungguhnya orang yang paling baik yang kamu ambil untuk bekerja (pada kita) ialah orang yang kuat lagi dapat dipercaya". 20

Ayat diatas menjelaskan mengenai usaha dalam pencarian tenaga kerja atau karyawan yang layak untuk direkrut adalah tenaga kerja yang memiliki kekuatan yang sesuai dengan pekerjaannya. Selain itu tenaga kerja harus memiliki sifat yang jujur serta amanah. Islam melarang adanya kecendurungan terhadap golongan tertentu, praktik

\footnotetext{
16 Luila, V. Pengembangan Fungsi Manajemen Sumber Daya Manusia Pada Pt Ageless Aesthetic Clinic. Agora, 1(3), 2013. 1711-1719.

17 Luila, V, Pengembangan Fungsi..., hal.2.

${ }^{18}$ Muzakki, M., Eliyana, A., \& Muhtadi, R. Is employee performance affected by organizational cuoture, work motivation and organizational citizenship behavior (OCB)?: An empirical investigation. IJIEEB International Journal of Integrated Education, Engineering and Business eISSN 2615-1596 pISSN 2615-2312, 2(1), 2019. 3642.

${ }^{19}$ Edy Sutrisno. Manajemen Sumber Daya Manusia. (Jakarta: Prenadamedia Group, 2009), hal.45.

${ }^{20}$ Edy Sutrisno, Manajemen Sumber.., hal.46.

${ }^{21}$ Departemen Agama Islam RI, Mushaf Al-Quran dan Terjemah.., QS. Al-Qashas 28:26
} 
penipuan serta tindakan kezaliman dalam proses rekrutmen calon tenaga kerja atau karyawan. ${ }^{22}$

Proses rekrutmen nanti akan menghasilkan sejumlah tenaga kerja yang sudah melewati tahap awal seperti ketika calon karyawan atau tenaga kerja di cari, surat lamaran masuk sampai pada tahap penerimaan lamaran yang telah diajukan oleh calon karyawan atau tenaga kerja yang selanjutnya akan memasuki tahapan peyeleksian calon karyawan. ${ }^{23}$ Seleksi calon karyawan merupakan tahap pemilihan serta penentuan dari sejumlah pelamar dengan mempertimbangkan calon karyawan atau pelamar yang paling memenuhi kriteria yang sudah ditetapkan oleh perusahaan berdasarkan kebutuhan dan posisi yang diperlukan, serta perkiraan tetntang kemampuan seorang pelamar atau calon karyawan untuk memenuhi tugas yang nanti akan menjadi tanggung jawabnya. ${ }^{24}$

Proses seleksi calon karyawan dalam perspektif Islam adalah suatu persoalan yang krusial. Kegiatan seleksi merupakan pemeilihan atau penentuan calon karyawan yang dilakukan oleh pihak perusahaan secara selektif agar mendapatkan tenga kerja atau karyawan yang memiliki kompetensi serta keahlian sesuai dengan bidang pekerjaannya, juga menguasai pengetahuan yang luas serta memiliki sifat amanah dan juga bertanggung jawab atas kewajibannya, ${ }^{25}$ hal ini sesuai dengan hadist Rosulullah SAW., yang diriwayatkan Imam Bukhari dari Abu Hurairah., Rosulullah SAW., bersabda "Ketika engkau menyia-nyiakan amanah maka tunggulah kehancurannya. Dikatakan, wahai Rasulullah, apa yang membuatnya sia-sia? Rasul menjawab: "Ketika suatu perkara/pekerjaan diserahkan kepada orang yang bukan ahlinya, maka tunggulah saat kehancurannya".(HR. Bukhari).

\section{Penilaian Kinerja Karyawan}

Achmad S.Ruky mengutip atas pernyataan Bernadin dan Russel yang mendefinisikan kinerja atau prestasi adalah catatan tentang hasil-hasil yang diperoleh dari fungsi-fungsi kegiatan tertentu atau pekerjaan tertentu selama kurun waktu tertentu. Sedangkan menurut Soeprihanto, kinerja atau prestasi kerja merupakan ketentuan awal yang telah disepakati mengenai pencapaian dari hasil kerja seseorang karyawan dalam periode yang sudah ditentukan, misalnya target,standar, sasaran, atau kriteria yang telah ditentukan terlebih dahulu dan disepakati bersama. Menurut Sentngono, kinerja atau prestasi kerja yaitu bersangkutan dengan pencapaian kerja seseorang sesuai dengan wewenang dan tanggung jawab berdasarkan tugas baik itu secara individual ataupun kelompok yang ada didalam suatu perusahaan atau organisasi tertentu. Jadi penilaian

\footnotetext{
22 Wahyuni, "TELAAH KRITIS PENERAPAN MANAJEMEN SUMBER DAYA INSANI PADA PERUSAHAAN (Studi Empiris Pada PT. Bank Muamalat Indonesia, Tbk. Cabang Bengkulu."

23 Abu Fahmi, dkk. HRD Syariah Teori dan Implementasi, (Jakarta: PT. Gramedia Pustaka Utama, 2014), hal.158.

24 R. Wayne Mondy. Manajemen Sumber Daya Manusia, (Jakarta: Erlangga, 2008), hal.168.

${ }^{25}$ Eka Sri Wahyuni. 2017. Telaah Kritis Penerapan Manajemen Sumber Daya Insani pada Perusahaan. Jurnal Baabu Al-Ilmi. Vol.2 No.1, hal.145.
} 
kinerja dapat disimpulkan sebagai aktivitas yang dilakukan perusahaan untuk mengukur dan mengevaluasi pelaksanaan kerja karyawan kepada perusahaan selama periode tertentu. ${ }^{26}$

Penilaian kerja dalam perspektif syariah merupakan proses perencanaan, pemantauan serta pengevaluasian terhadap kompetensi syariah para karyawan. Kompetensi syariah perlu dilakukan dan dikembangkan karena sejalan dengan perusahaan yaitu menyelaraskan antara bisnis dan mardhotillah. ${ }^{27}$

\section{Pelatihan dan Pengembangan}

Definisi pelatihan (training) menurut Rivai dan Simamora yang dikutip oleh Eka Sri Wahyuni merupakan suatu cara yang telah diatur oleh perusahaan dari sisi watak, kebiasaan dan juga tindakan karyawan yang aka diarahkan kepada hal-hal yang nantinya akan memudahkan tercapainya setiap tujuan dan visi misi perusahaan. Pelatihan karyawan mempunyai tujuan untuk mengutamakan kemampuan dan juga keahlian seorang karyawan agar bisa maksimal dan bisa memenuhi kebutuhan sesuai dengan pekerjaannya, karena pemenuhan kompetensi yang sesuai dengan keahlian, kebiasaan juga tindakan karyawan akan mempermudah untuk melaksanakan pekerjaannya. ${ }^{28}$ Artinya, tujuan dari adanya pelatihan karyawan untuk meningkatkan kompetensi karyawan baik itu dari ilmu pengetahuan ataupun keahlian yang dimiliki karyawan.

Pengembangan (Development) merupakan pendidikan serta pelatihan yang diberikan kepada karyawan untuk menambah kualitas potensi baik itu secara moral, kedispinan, produktivitas serta kompetensi karyawan yang nanti bisa direalisasikan melalui pelatihan dan pendidikan. ${ }^{29}$ Pengembangan biasanya berhubungan dengan peningkatan kompetensi, produktivitas, disiplin, sikap, moral dan etos kerja karyawan yang dilakukan melalui pelatihan.

Pengembangan karyawan melalui proses pendidikan nantinya akan meningkatkan keahlian karyawan dari aspek teori, konsep serta moral karyawan. Sedangkan pengembangan karyawan yang diberikan melalui tahap pelatihan bertujuan untuk mengoptimalkan keterampilan karyawan dlam bidang pekerjaannya. ${ }^{30}$ Pelatihan (training) dan pengembangan (development) pada prinsipnya memiliki tujuan untuk meningkatkan kompetensi karyawan secara optimal pada suatu perusahaan dalam mencapai tujuan yang telah direncanakan sesuai dengan visi dan misi perusahaan.

\footnotetext{
${ }^{26}$ Abu Fahmi, dkk. HRD Syariah..., hal.179.

${ }^{27}$ Abu Fahmi, dkk. HRD Syariah..., hal.183.

${ }^{28}$ Eka Sri Wahyuni, Telaah Kritis penerapan Manajemen Sumber Daya Insani pada Perusahaan, Jurnal Baabu Al-Ilmi. Vol.2 No.1. hal.146.

29 Eka Sri Wahyuni, Telaah Kritis.... hal.146.

30 Malayu Hasibuan, Manajemen Sumber Daya Manusia, (Jakarta: Bumi Aksara, 2009) hal. 69
} 


\section{METODE PENELITIAN}

Penelitian yang dipilih oleh peneliti adalah deskriptif dengan menggunakan metode pendekatan kualitatif untuk bisa mengetahui suatu keadaan atau situasi bahkan proses seacara terperinci dan jelas mengenai penerapan manajemen sumber daya insani di PT. BPRS Sarana Prima Mandiri (SPM) Pamekasan. Penelitian ini akan dilakukan di PT. BPRS Sarana Prima Mandiri (SPM) Pamekasan yang beralamat di Jl. Agus Salim 20 Pamekasan.

Adapun sumber data yang digunakan peneliti yaitu data primer dan data sekunder. Data primer dalam penelitian ini merupakan hasil wawancara peneliti dengan salah satu ketua pimpinan kantor kas, kabag marketing serta bagian kasi SDI. Data sekunder ini merupakan pelengkap dari data primer yang perolehan datanya tidak didapatkan secara langsung dari subjek penelitian, data yang diperoleh peniliti bisa didaptkan melalui laporan penelitian yang sudah ada atau dari perpustakaan, majalah, koran, jurnal dan lain sebagainya yang tentunya berkaitan dengan kebutuhan penelitian.

Teknik pengumpulan data yang dipilih oleh peneliti adalah Observasi, Wawancara, dan Dokumentasi. Pada teknik pengumpulan data melalui observasi ini peneliti menggunakan observasi tidak terstruktur. Peneliti tidak menggunakan pedoman observasi, sehingga peneliti mengembangkan pengamatan berdasarkan perkembangan yang terjadi di lapangan mengenai manajemen sumber daya insani dalam pengelolaan PT. BPRS Sarana Prima Mandiri (SPM) Pamekasan. Selain observasi wawancara juga merupakan cara yang strategis untuk memperoleh data yang akurat. Wawancara dilakukan dengan cara Tanya jawab, sambil bertatap muka antara peneliti dengan responden yang dianggap dapat memberikan informasi data yang tepat yaitu dengan salah satu ketua pimpinan kantor kas serta kabag marketing serta bagian kasi SDI. Sedangkan teknik pengumpulan data dengan cara dokumentasi ini, peneliti mencari peristiwa yang telah lalu yang ada di PT. BPRS Sarana Prima Mandiri (SPM) Pamekasan baik itu yang berupa tulisan, gambar dan karya-karya monumental lainnya.

Data-data yang telah diperoleh oleh peneliti dari beberapa sumber, akan dianalisis dengan menggunakan proses redukasi data, penyajian data dan verifikasi data. Kesimpulan dalam penelitian ini bukanlah suatu karangan atau diambil dari pembicaraan-pembicaraan lain, akan tetapi hasil dari suatu proses tertentu.

\section{HASIL DAN PEMBAHASAN}

\section{Implementasi Manajemen Sumber Daya Insani di PT. BPRS Sarana Prima Mandiri (SPM) Pamekasan.}

Berikut hasil penelitian yang peneliti lakukan mengenai implementasi manajemen sumber daya insani pada aspek rekrutmen, seleksi, pelatihan, pengembangan, penilaian kineja karyawan serta kompensasi di PT. BPRS Sarana Prima Mandiri (SPM) Pamekasan. 


\section{Rekrutmen}

Rekrutmen adalah proses awal dimana seorang calon karyawan mengetahui informasi tentang adanya lowongan kerja dalam perusahaan. Berdasrkan dari hasil wawancara dengan bagian SDI, dijelaskan bahwa proses dalam rekrutmen yang diterapkan di PT. BPRS Sarana Prima Mandiri (SPM) Pamekasan sebagai berikut:

\section{Open recruitmen.}

Tahap untuk open recruitmen di PT. BPRS Sarana Prima Mandiri (SPM) Pamekasan itu selalu membuka rekrutmen, artinya setiap calon karyawan atau para pelamar kerja dapat memasukkan surat lamaran kerja kapan saja, ketika perusahaan (PT. BPRS Sarana Prima Mandiri (SPM) Pamekasan) membuka kantor cabang baru atau ada beberapa karyawan yang melakukan resign maka secara tidak langsung perusahaan membutuhkan karyawan baru untuk menempati posisi atau jabatan yang kosong. Bagian kasi SDI nanti akan memanggil pelamar dari lamaran-lamaran pekerjaan sebelumnya yang sudah ada dan memenuhi kriteria. ${ }^{31}$

2. Media rekrutmen.

Media yang paling sering digunakan oleh PT. BPRS Sarana Prima Mandiri (SPM) Pamekasan dalam proses rekrutmen yaitu media internet. Informasi lowongan pekerjaan dalam proses rekrutmen juga akan dilengkapi dengan job specification dan man specification yang disesuaikan dengan lowongan pekerjaan di PT. BPRS Sarana Prima Mandiri (SPM) Pamekasan. ${ }^{32}$

Tahapan yang harus dilakukan oleh calon karyawan atau pelamar dalam proses rekrutmen yaitu harus lolos dari analisis yang dilakukan bagian kasi SDI PT. BPRS Sarana Prima Mandiri Pamekasan dengan mempertimbangkan surat lamaran yang masuk, apakah sudah sesuai dengan syarat-syarat yang telah diinformasikan sebelumnya baik itu dari job specification dan man specification yang telah ditetapkan oleh perusahaan. Calon karyawan atau pelamar yang terpilih dan sudah memenuhi persyaratan yang sudah ditetapkan oleh perusahaan nantinya akan melakukan wawancara singkat terkait tujuan serta motivasi calon karyawan atau pelamar ingin bergabung dengan PT. BPRS Sarana Prima Mandiri (SPM) Pamekasan. Wawancara singkat ini biasanya dilakukan oleh bagian kabag operasional, kabag marketing da direktur PT. BPRS Sarana Prima Mandiri (SPM) Pamekasan selaku pewawancara. Calon karyawan yang berhasil melewati tahap wawancara singkat ini nantinya akan mengikuti tahap seleksi calon karyawan.

Penerapan proses rekrutmen calon karyawan yang diterapkan di PT. BPRS Sarana Prima mandiri (SPM) Pamekasan, sudah sesuai denga teori syariah. Sebab dalam

\footnotetext{
31 Wawancara, Ikbal selaku Kasi. Funding PT. BPRS Sarana Prima Mandiri (SPM) Pamekasan, pada 06 Oktober 2020

32 Wawancara, Gita selaku Kasi. SDI PT. BPRS Sarana Prima Mandiri (SPM) Pamekasan, pada 07 Oktober 2020
} 
proses rekrutmen yang sudah diterapkan tidak ada lagi kecenderungan terhadap golongaan tertentu serta tindakan penipuan dan kezaliman terhadap calon karyawan.

\section{Seleksi}

Terdapat beberapa tahapan dalam proses seleksi calon karyawan untuk dapat diterima sebagai karyawan di PT. BPRS Sarana Prima Mandiri (SPM) Pamekasan. Selain kelengkapan yang harus dipenuhi secara administratif, ada beberapa tahapan seleksi calon karyawan sebagaimana berikut:

1. Tes Tertulis

Tes tertulis merupakan tahapan awal dari proses seleksi dimana semua calon karyawan akan di tes mengenai pemahamannya mengenai perbankan syariah terkait dengan pengetahuan pelamar atau calon karyawan mengenai hal-hal yang ada di perbankan syariah seperti jenis produk perbankan syariah, akad-akad pada setiap transaksi dalam perbankan syariah dan lain sebagainya. Selain tes tertulis seperti yang sudah disebut diatas, ada juga tes Bahasa Inggris untuk mengetahui kemampuan seorang calon karyawan dalam berbahasa inggris (Toefl Test). sehingga bisa menjadi nilai tambah dari seorang calon karyawan untuk bisa bergabung di PT. BPRS Sarana Prima Mandiri (SPM) Pamekasan. Kemampuan calon karyawn dalam mengoperasikan komputer juga akan menjadi pertimbangan dalam penialian pada tahap seleksi.

2. Psikotes

PT. BPRS Sarana Prima Mandiri (SPM) Pamekasan melakukan psikotes pada setiap pelamar untuk mengetahui bagaimana sifat ataupun karakter calon karyawan dengan melakukan wawancara tentang hal-hal yang berkaitan dengam psikologis seseorang.

\section{Tes Kesehatan}

Tes kesehatan merupakan tahap terakhir dari proses seleksi. Calon karyawan atau pelamar harus dinyatakan sehat secara jasmani ataupun rohani dari hasil medical chek up yang sudah dilakukan. Ketiga tahap seleksi yang telah disebutkan maka akan menghasilkan rekomendasi calon karyawan yang dinyatakan diterima di PT. BPRS Sarana Prima Mandiri (SPM) Pamekasan. ${ }^{33}$

Proses seleksi di PT. BPRS Sarana Prima Mandiri (SPM) Pamekasan sesuai dengan tahapan yang sudah diterapkan sudah sesuai dengan konsep syariah, karena seleksi calon karyawan dilakukan dengan memperimbangkan kemampuan yang dimiliki oleh calon karyawan yang penilaiannya meliputi: tingkat pemahaman calon karyawan tentang perbankan syariah, tingkat kesesuian karakter, sifat serta sikap

${ }_{33}$ Wawancara, Sutrisno selaku Kabag. Marketing PT. BPRS Sarana Prima Mandiri (SPM) Pamekasan, pada 19 Oktober 2020 
calon karyawan dengan pekerjaannya apakah sudah bisa menajalankan pekerjaan dengan sifat amanah dan tanggung jawab, dan tahap terakhir pemenuhan tes kesehatan. Calon karyawan atau pelamar yang lolos dari tiga tahap tersebut kemudian dinyatakan terpilih dan bisa bergabung dengan PT. BPRS Sarana Prima Mandiri (SPM) Pamekasan.

\section{Pelatihan (Training)}

Proses pelatihan (training) dalam meningkatkan kompetensi karyawan di di PT. BPRS Sarana Prima Mandiri (SPM) Pamekasan ada beberapa cara dan bagian waktu tertentu yaitu:

1. Pelatihan (training) dalam satu minggu yang dilakukan oleh PT. BPRS Sarana Prima Mandiri (SPM) Pamekasan, diperuntukkan karyawan yang baru bergabung. Dalam waktu seminggu tersebut karyawan akan diberikan materi tentang akad-akad syariah dan produk-produk syariah yang digunakan dan dimiliki oleh PT. BPRS Sarana Prima Mandiri (SPM) Pamekasan. ${ }^{34}$

2. Pelatihan (training) yang dilakukan setiap tahunan oleh kantor. Pada proses pelatihan yang diadakan oleh PT. BPRS Sarana Prima Mandiri (SPM) Pamekasan semua karyawan diikutsertakan dengan materi yang bisa ditentukan sendiri oleh pihak PT. BPRS Sarana Prima Mandiri (SPM) Pamekasan materi yang disampaikan lebih kepada bagaimana cara seseorang yang professional dalam bekerja serta materi mengenai orientasi bisnis dengan mendatangkan nara sumber atau pemateri dari luar. ${ }^{35}$

3. Pelatihan (training) yang diadakan oleh lembaga keuangan syariah lainnya. Karyawan yang ikut dalam kegiatan pelatihan ini nantinya disesuaikan dengan materi pelatihan serta jabatannya. ${ }^{36}$

\section{Pengembangan (development)}

Pengembangan (development) yang dilakukan oleh PT. BPRS Sarana Prima Mandiri (SPM) Pamekasan yaitu dengan melakukan pemindahan karyawan dari satu jabatan ke jabatan yang lainnya seperti dari kasi operasional mangalmi peningkatan jabatan menjadi kabag operasional atau pemindahan karyawan dari satu tempat ke tempat yang lainnya seperti pemindahan ketua pimpinan canbang di wilayah tertentu ke wilayah yang lain.

\footnotetext{
${ }^{34}$ Wawancara, Suhari selaku Ketua Pimpinan Kantor Kas Bandaran PT. BPRS Sarana Prima Mandiri (SPM) Pamekasan, pada 14 Oktober 2020

35 Wawancara, Sutrisno selaku Kabag. Marketing PT. BPRS Sarana Prima Mandiri (SPM) Pamekasan, pada 19 Oktober 2020

36 Wawancara, Sutrisno selaku Kabag. Marketing PT. BPRS Sarana Prima Mandiri (SPM) Pamekasan, pada 19 oktober 2020
} 
Pada proses pengembangan karyawan ini, perubahan karyawan dari segi jabatan atau penempatan wilayah merupakan pertimbangaan dari kesesuaian kemampuan karyawan yang ditunjukkan dari hasil pekerjaanya. ${ }^{37}$

\section{Penilaian Kinerja Karyawan}

Penilaian kinerja karyawan di PT. BPRS Sarana Prima Mandiri (SPM) Pamekasan dilakukan dengan mempertimbangkan kedispilinan karyawan terkait jam kerja, keaktifan karyawan dalam bidang pekerjaanyya serta kemampuan karyawan dalam pencapaian target yang sudah ditentukan oleh perusahaan. Penilaian kinerja untuk pencapaian target terbagi menjadi dua yang pertama untuk bagian karyawan di bagian marketing yang terdiri dari marketing funding yang penialain kerjanya berorientasi pada pemerolehan dana apakah sudah menghimpun dana sesuai dengan target atau tidak, untuk marketing landing penilaian kinerja karyawannya hampir sama dengan bagian marketing funding, hanya saja untuk marketing landing dilihat dari seberapa banyaknya nasabah yang di peroleh serta pencairan pembiayaan yang dilakukan apakah sudah mencapai target yang di tentukan perusahaan. Sedangkan penilaian kinerja karyawan yang ada dibagian operasional yaitu dengan mengukur mengenai kedisiplinan waktu kerjanya, ketepatan pembuatan laporan serta mengenai aktivitasnya dalam menjalankan sistem operasional yang ada di perusahaan apakah sudah benar atau tidak.

Sistem penilaian kinerja terhadap karyawan ini nantinya akan akan mempengaruhi terhadap kompensasi. Karyawan yang telah kinerjanya telah mencapai target tentunya nanti akan mendapatkan reward baik itu secara langsung berupa financial atau naik jabatan bisa juga berupa bentuk bonus lainnya yang nanti akan di berika oleh perusahaan. ${ }^{38} \quad$ Tujuan dari penerapan penilaian kinerja karyawan ini untuk bisa meningkatkan prestasi kerja dari karyawan tentu sesuai dengan bagiannya tertentu sehingga bisa di-evaluasi dan bisa membantu perusahaan untuk merencanakan dan mempersiapkan kebutuhan karyawan dalam pencapaian tujuan perusahaan seperti halnya penyusunan program pelatihan dan pengembangan karyawan yang lebih tepat, untuk mempersiapkan sarana dalam pencapaian tujuan baik itu berupa gaji atau reward.

\section{Kesimpulan}

Penerapan manajemen sumber daya insani di PT. BPRS Sarana Prima Mandiri (SPM) Pamekasan dari proses rekrutmen dan seleksi yang dilakukan sudah sesuai denga teori syariah. Sebab jika dilihat dari cara dalam proses rekrutmen karyawan sudah tidak ada lagi unsur nepotisme, tindak kezaliman, penipuan, intimidasi atau kecenderungan terhadap golongaan tertentu. Sedangkan dalam tahap pelatihan (training) dan pengembangan

\footnotetext{
${ }^{37}$ Wawancara, Suhari selaku Ketua Pimpinan Kantor Kas Bandaran PT. BPRS Sarana Prima Mandiri (SPM) Pamekasan, pada 14 Oktober 2020

38 Wawancara, Sutrisno selaku Kabag. Marketing PT. BPRS Sarana Prima Mandiri (SPM) Pamekasan, pada 19 Oktober 2020
} 
(development) yang diberikan kepada karyawan yaitu mengenai materi tentang muamalah dan materi mengenai dasar-dasar perbankan syariah sehingga tidak ada lagi kekhawatiran mengenai praktik dan transaksi yang tidak sesuai dengan dasar-dasar ekonomi syariah, juga matei yang disesuaikan dengan jabatannya. Proses pelatihan (training) dan pengembangan (development) di PT. BPRS Sarana Prima Mandiri (SPM) Pamekasan masih kurang seimbang untuk syariah skill atau juga dapat dipahami sebagai syariah competence yang biasanya diisi dengan pelatihan atau workshop mengenai: tauhid (Akidah), syariah, muamalah adalah suatu kesatuan, bukan hanya sekedar memfokuskan diri pada materi Fikih Muamalah saja. Penlaian kinerja karyawan di PT. BPRS Sarana Prima Mandiri (SPM) Pamekasan juga syariah sesuai dengan konsep syariah.

\section{DAFTAR PUSTAKA}

Ali, Muhammad. Kamus Lengkap Bahasa Indonesia Modern. Jakarta: Pustaka Amani, 2006. Aziz, Abdul. Manajemen Investasi Syariah. Bandung: alfabeta, 2010.

Departemen Agama. (2002). Mushaf Al-Quran Terjemah. Depok. Firdaus,

Fahmi, A. (2014). HRD syariah: teori dan implementasi: manajemen sumber daya manusia berbasis syariah. PT Gramedia Pustaka Utama.

Harahap, Sari Rezeki. "PENGARUH STRATEGI PENGEMBANGAN SUMBER DAYA INSANI TERHADAP PENINGKATAN KINERJA DAN MUTU PELAYANAN PADA PT. BANK MUAMALAT INDONESIA, Tbk CABANG MEDAN." Journal Analytica Islamica 5, no. 1 (8 Mei 2016): 149-68.

Hariandja, M. T. E. (2002). Manajemen sumber daya manusia. Grasindo.

Hasibuan, M. S. (2009). Manajemen Sumber Daya Manusia, Jakarta: Bumi Aksara.

Herry, Ervicaninda, Pramudia Yuli Eka Permana, Wisnu Bayu Aji, dan Ridan Muhtadi. "Total Quality Management Development and Sharia Governance Efforts in Sharia Micro Financial Institutions to Improve Market Share." IJIEEB: International Journal of Integrated Education, Engineering and Business 2, no. 1 (2019): 27-35. https://doi.org/10.29138/ijieeb.v2i1.809.

Lubis, M. Z. M. (2020) POLA REKRUTMEN DAN SELEKSI KARYAWAN PADA BMT. FreakonomicS: Journal of Islamic Economics and Finance, 1(1). 23-33.

Luila, V. (2013) Pengembangan Fungsi Manajemen Sumber Daya Manusia Pada Pt Ageless Aesthetic Clinic. Agora, 1(3). 1711-1719.

Muhtadi, Ridan. "SINERGISME BAITUL MAAL WA TAMWIL ( BMT ) DENGAN BADAN," 2015, 143-52.

Muslikhin, M., Kinanti, R. A., Muhtadi, R., \& Fudholi, M. (2020) PEMERIKSAAN EMPIRIS PADA PENGARUH KINERJA SOSIAL TERHADAP PROFITABILITAS DI BANK SYARIAH. Ulumuna: Jurnal Studi Keislaman, 6(1). 72-84

Muzakki, M., Eliyana, A., \& Muhtadi, R. (2019). Is employee performance affected by organizational cuoture, work motivation and organizational citizenship behavior (OCB)?: An empirical investigation. IJIEEB International Journal of Integrated 
Education, Engineering and Business eISSN 2615-1596 pISSN 2615-2312, 2(1), 3642.

Nur Alfi, Azizah. "Pangsa Pasar Bank Syariah Belum Naik Signifikan, Ini Tantangannya | Finansial." Bisnis.Com, 3 September 2020, bag. FINANSIAL. https://finansial.bisnis.com/read/20200903/90/1286919/pangsa-pasar-banksyariah-belum-naik-signifikan-ini-tantangannya.

R. Wayne Mondy. (2008). Manajemen Sumber Daya Manusia. Jakarta: Erlangga

Rosyadah, P. C., Arifin, N. R., Muhtadi, R., \& Safik, M. (2020). Factors That Affect Savings In Islamic Banking. AL-ARBAH: Journal of Islamic Finance and Banking, 2(1), 33-46.

Suryani, Yani, dan Cecep Darmawan. Kiat Sukses Manajemen Rasulullah:Manajemen Sumber daya Insani Berbasis Nilai-nilai Ilahiyah. Bandung: Khazanah Intelektual, 2006.

Sutrisno, Edy. Manajemen Sumber Daya Manusia. Jakarta: Kencana prenada media group, 2011.

Wahyuni, Eka Sri. "TELAAH KRITIS PENERAPAN MANAJEMEN SUMBER DAYA INSANI PADA PERUSAHAAN (Studi Empiris Pada PT. Bank Muamalat Indonesia, Tbk. Cabang Bengkulu." Jurnal BAABU AL-ILMI: Ekonomi dan Perbankan Syariah 2, no. 1 (25 April 2017). https://doi.org/10.29300/ba.v2i1.1051.

https://https://www.metrotvnews.com/play/bD7UA1PE-90-pegawai-perbankansyariah-tidak-berlatar-pendidikan-ekonomi-syariah. 90\% Pegawai Perbankan Syariah Tidak Berlatar Pendidikan Ekonomi Syariah. 